\title{
Development of Gonadotropin-Releasing Hormone Secretion and Pituitary Response
}

\author{
DKatarzyna M. Glanowska, ${ }^{1}$ Laura L. Burger, ${ }^{2}$ and Suzanne M. Moenter ${ }^{2,3,4}$ \\ ${ }^{1}$ Neuroscience Graduate Program, University of Virginia, Charlottesville, Virginia 22908, and Departments of ${ }^{2}$ Molecular and Integrative Physiology, \\ ${ }^{3}$ Internal Medicine, and ${ }^{4}$ Obstetrics and Gynecology, University of Michigan, Ann Arbor, Michigan 48109
}

Acquisition of a mature pattern of gonadotropin-releasing hormone $(\mathrm{GnRH})$ secretion from the CNS is a hallmark of the pubertal process. Little is known about $\mathrm{GnRH}$ release during sexual maturation, but it is assumed to be minimal before later stages of puberty. We studied spontaneous GnRH secretion in brain slices from male mice during perinatal and postnatal development using fast-scan cyclic voltammetry (FSCV) to detect directly the oxidation of secreted GnRH. There was good correspondence between the frequency of GnRH release detected by FSCV in the median eminence of slices from adults with previous reports of in vivo luteinizing hormone (LH) pulse frequency. The frequency of $\mathrm{GnRH}$ release in the late embryonic stage was surprisingly high, reaching a maximum in newborns and remaining elevated in 1-week-old animals despite low LH levels. Early high-frequency GnRH release was similar in wild-type and kisspeptin knock-out mice indicating that this release is independent of kisspeptin-mediated excitation. In vivo treatment with testosterone or in vitro treatment with gonadotropin-inhibitory hormone $(\mathrm{GnIH})$ reduced $\mathrm{GnRH}$ release frequency in slices from 1-week-old mice. RF9, a putative $\mathrm{GnIH}$ antagonist, restored $\mathrm{GnRH}$ release in slices from testosterone-treated mice, suggesting that testosterone inhibition may be GnIH-dependent. At 2-3 weeks, GnRH release is suppressed before attaining adult patterns. Reduction in early life spontaneous GnRH release frequency coincides with the onset of the ability of exogenous $\mathrm{GnRH}$ to induce pituitary $\mathrm{LH}$ secretion. These findings suggest that lack of pituitary secretory response, not lack of $\mathrm{GnRH}$ release, initially blocks downstream activation of the reproductive system.

Key words: cyclic voltammetry; gonadotropin inhibitory hormone; gonadotropin releasing hormone; puberty; testosterone

\section{Introduction}

Puberty leads to full sexual maturation and involves both physiological and behavioral changes. This complex process occurs on multiple levels including gene expression, epigenetic modifications, and functional reorganization of neuronal and glial networks in the brain regions controlling reproduction (Seminara and Crowley, 2001; Krewson et al., 2004; Ojeda et al., 2010; Poling et al., 2012; Lomniczi et al., 2013). From a neuroendocrine perspective, in vertebrates the pubertal process is thought to culminate in the activation of the gonadotropin-releasing hormone (GnRH) neural network (Foster and Jackson, 2006; Ojeda and Skinner, 2006); in primates, this network is reactivated at puberty following a neonatal elevation in pituitary gonadotropin levels (and presumably GnRH release) that is subsequently suppressed during the juvenile period (Plant and Witchel, 2006). In other

Received May 30, 2014; revised Sept. 12, 2014; accepted 0ct. 2, 2014.

Author contributions: K.M.G., L.L.B., and S.M.M. designed research; K.M.G. and L.L.B. performed research; K.M.G., L.L.B., and S.M.M. analyzed data; K.M.G. and S.M.M. wrote the paper.

This work was supported by National Institute of Health/Eunice Kennedy Shriver National Institute of Child Health and Human Development Grant R01 HD34860. We thank Elizabeth Wagenmaker for expert technical assistance, the University of Virginia Center for Research in Reproduction Ligand Assay and Analysis Core, supported by the Eunice Kennedy Shriver NICHD/NIH (SCCPIR) Grant U54-HD28934 for assays, and Drs Seminara and Chan for sharing the kisspeptin $\mathrm{KO}$ mice.

The authors declare no competing financial interests.

Correspondence should be addressed to Dr Suzanne M. Moenter, 7725 Med Scill, 1137 East Catherine Street, Ann Arbor, Ml 48109-5622. E-mail: smoenter@umich.edu.

DOI:10.1523/JNEUROSCI.2200-14.2014

Copyright $\odot 2014$ the authors $\quad 0270-6474 / 14 / 3415060-10 \$ 15.00 / 0$ species, a similar prolonged increase in gonadotropins during early postnatal life does not occur. In mice, luteinizing hormone (LH) in females and testosterone in males is elevated during the first $4 \mathrm{~h}$ after birth (Poling and Kauffman, 2012). The testosterone elevation is not dependent upon $\mathrm{GnRH}$ and may reflect residual independent Leydig cell steroidogenesis, which peaks at embryonic day (E)18 (O'Shaughnessy et al., 1998). LH levels in male mice remain low until a mild increase $\sim 12-15 \mathrm{~d}$ postpartum (Selmanoff et al., 1977; Michael et al., 1980), followed by an increase to sexual maturity when pulses of LH are detected every 2-3 h (Coquelin and Desjardins, 1982).

In adults, GnRH pulses released from the median eminence (ME) into pituitary portal blood strongly correlate with $\mathrm{LH}$ pulses in peripheral circulation (Moenter et al., 1992). This strong correlation in adulthood has lead to the logical assumption that low levels of gonadotropins typically observed during first days to weeks of life reflect relative inactivity of $\mathrm{GnRH}$ release, although sporadic increases may indicate infrequent $\mathrm{GnRH}$ secretion (Goldman et al., 1971; Dohler and Wuttke, 1974; MacKinnon et al., 1976; Selmanoff et al., 1977; Michael et al., 1980). The subsequent persistent rise in LH levels during later development is considered to mark the onset of GnRH pulse generator activity. Consistent with this postulate, the frequency of $\mathrm{GnRH}$ release from isolated rat retrochiasmatic brain explants increased from days 12 to 27 (Bourguignon and Franchimont, 1984), as did in vivo GnRH release frequency in late pubertal monkeys and rats (Watanabe and Terasawa, 1989; Sisk et al., 

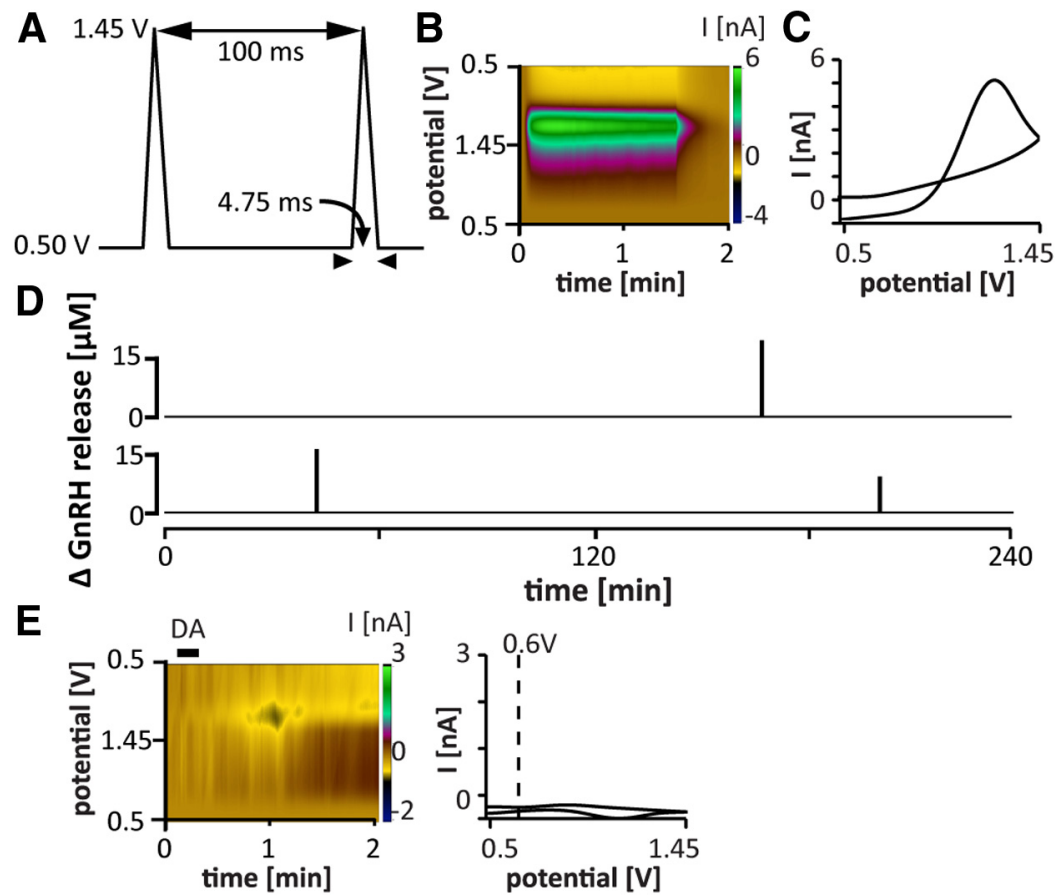

Figure 1. Pattern of GnRH release detected in the ME of brain slices in adults. A, FSCV waveform;holding potential $0.5 \mathrm{~V}$, switching potential $1.45 \mathrm{~V}$, scan rate $-400 \mathrm{~V} / \mathrm{s}$ (adapted from (Glanowska et al., 2012). B, Pseudo-color representation of current changes (color scale) as a function of time ( $x$-axis) and potential ( $y$-axis) for representative spontaneous $G n R H$ release in the ME of a brain slice from an adult male mouse. C, Background-subtracted cyclic voltammogram for the spontaneous event shown in $\boldsymbol{B}$. $\boldsymbol{D}$, Two representative examples of the pattern of spontaneous $\mathrm{GnRH}$ release in adults. Summary data are shown in Figure 2 for ease of comparison with other developmental stages. $E$, Application of dopamine (DA, $10 \mu \mathrm{m}$, black bar) did not produce a current signal with the waveform used to detect GnRH. Left, Pseudo-color representation of current changes; right, background-subtracted cyclic voltammogram. Dotted line indicates voltage value for stereotypical dopamine oxidation peak.

2001), although it is important to point out that LH was not monitored during these studies, nor were earlier ages examined.

The understanding of development of GnRH release that emerges from the above studies is hampered by the need to interpolate dynamic changes in GnRH release from single samples measuring downstream gonadotropin levels; these samples are often terminal and/or pooled among separate subjects. At present, there are no direct measurements of the pattern of GnRH release from the embryonic stage through completion of puberty in any species. Here we used fast-scan cyclic voltammetry (FSCV), an electrochemical method that can directly quantify changes in GnRH release (Glanowska et al., 2012), to examine the developmental profile of $\mathrm{GnRH}$ release in the $\mathrm{ME}$ and to study its regulation.

\section{Materials and Methods}

Animals and brain slice preparation. GnRH-eGFP (Suter et al., 2000) or kisspeptin knock-out (KO; Chan et al., 2009; Lapatto et al., 2007) male mice were housed under a 14:10 h light/dark photoperiod with Harlan 2916 chow and water available ad libitum. On the day of study, brain slices were prepared as described previously (Nunemaker et al., 2002; Chu and Moenter, 2005). All chemicals were obtained from SigmaAldrich unless noted. All buffers were bubbled with $95 \% \mathrm{O}_{2} / 5 \% \mathrm{CO}_{2} 15$ min before use. Brain slices $(300-350 \mu \mathrm{m})$ were cut using a Leica VT $1200 \mathrm{~S}$ Vibratome 3000 in ice-cold sucrose saline containing the following (in mM): 250 sucrose, $3.5 \mathrm{KCl}, 26 \mathrm{NaHCO}_{3}, 10$ D-glucose, $1.25 \mathrm{NaH}_{2} \mathrm{PO}_{4}$, $1.2 \mathrm{MgSO}_{4}$ and $3.8 \mathrm{MgCl}_{2}$. Slices were incubated at room temperature for $30 \mathrm{~min}$ in a 1:1 mixture of sucrose saline and artificial CSF (ACSF) containing the following (in mM): $125 \mathrm{NaCl}, 3.5 \mathrm{KCl}, 26 \mathrm{NaHCO}_{3}, 1.25$ $\mathrm{NaH}_{2} \mathrm{PO}_{4}, 2.5 \mathrm{CaCl}_{2}, 1.2 \mathrm{MgSO}_{4}$, and 10 D-glucose, $\mathrm{pH} 7.4$, and then transferred to $100 \%$ ACSF and incubated at room temperature 30-300 min before study.

FSCV recordings. Individual brain slices containing the ME, which is where neuroendocrine release of $\mathrm{GnRH}$ to control the pituitary gland occurs, were transferred to a recording chamber mounted on the stage of an upright microscope (Olympus BX50WI). The chamber was perfused with ACSF at a rate of 5-6 ml/ $\min$ at $31-32^{\circ} \mathrm{C}$. Slices were stabilized in the chamber for $>10$ min before recording. GnRH release was detected using carbon fiber microelectrodes (Glanowska et al., 2012). Microelectrodes were placed among GnRH fibers in the $\mathrm{ME}$ and stabilized for $15 \mathrm{~min}$ before collecting data. Potential was continuously scanned from 0.5 to $1.45 \mathrm{~V}$ at $400 \mathrm{~V} / \mathrm{s}$ every $100 \mathrm{~ms}$ (Fig. $1 \mathrm{~A}$ ). Signals arising from spontaneous release were recorded for $2-4 \mathrm{~h}$ in each individual slice. Release events separated by $<1$ min were counted as a single event for analysis, as the pituitary is unlikely to distinguish such events in vivo. Such short intervals were observed only at E18, postnatal day $(\mathrm{P}) 1$, and 1 week; the values reported for these ages are thus a conservative estimate of release frequency. To test whether dopamine produced a signal, 5-50 $\mu \mathrm{M}$ dopamine was injected near electrodes positioned in cortex.

To test the response to kisspeptin, kisspeptin 10 (10 $\mu \mathrm{M}$, Phoenix Pharmaceuticals) was locally injected into the ME 20-30 $\mu \mathrm{M}$ from the FSCV microelectrode. Further, spontaneous $\mathrm{GnRH}$ release was recorded from the ME of kisspeptin KO mice on E18 and P7. To test the effect of the inhibitory neuromodulator gonadotropin-inhibitory hormone $(\mathrm{GnIH}$; aka, RFRP3) on GnRH secretion at 1 week of age, a $1 \mathrm{~h}$ control recording period in ACSF solution was followed directly by a $1 \mathrm{~h}$ recording in ACSF containing 1 $\mu \mathrm{M}$ GnIH. To test the effect of testosterone, 1-week-old mice were injected subcutaneously with $50 \mathrm{mg} / \mathrm{kg}$ testosterone or sesame oil vehicle $4 \mathrm{~h}$ before brain slice preparation. To test whether GnIH mediated the effects of testosterone, RF9, which blocks both the putative the GnIH receptor GPR147, as well as GPR74, was used. Slices from testosteronetreated mice were incubated in ACSF containing $5 \mu \mathrm{M}$ RF9 for $1-3 \mathrm{~h}$ before and during recordings. RF9 does not cross the blood-brain barrier (Caraty et al., 2012), and this approach circumvented the need for intracerebroventricular injections in 1-week-old mice. To test whether RF9 alone could increase GnRH release, slices from 2-week-old mice were preincubated with RF9 as above, and the release monitored over 90 $\min$.

FSCV analysis. FSCV data were analyzed using Demon software (Wake Forest University Health Sciences) as described previously (Mundroff and Wightman, 2002; Glanowska et al., 2012; Gaskins et al., 2013). The analysis was preceded by data conversion using IgorPro software. Cyclic voltammograms (CVs) were background-subtracted by averaging 10 background scans. To verify the identity of a spontaneous release peak as $\mathrm{GnRH}, 10$ control CV s collected after GnRH was injected into a slice were averaged. Each putative GnRH CV was correlated with this average and was considered to be GnRH if $R^{2} \geq 0.8$. This threshold was set to allow for some electrode variability. $89 \%$ of CVs passed this test. Changes in GnRH concentration were estimated based on calibration in $5 \mu \mathrm{M}$ GnRH. Two-tailed parametric or nonparametric statistical tests (Graphpad Prism 6) were used where appropriate; $p<0.05$ was considered significant. Data are presented as mean \pm SEM.

Pituitary challenge to an exogenous GnRH pulse. Male mice ages 7, 14, and $21 \mathrm{~d}$, and adults $(93.4 \pm 6.5 \mathrm{~d})$ were randomly assigned to two treatment groups, saline or GnRH. GnRH (Bachem, H4005) was diluted to $25 \mathrm{ng} / \mathrm{ml}$ in $0.9 \%$ saline and mice were injected with $150 \mathrm{ng} / \mathrm{kg}$ or the 
Table 1. Integrative DNA technologies (IDT) qPCR assays for pituitary gene expression

\begin{tabular}{lllcc}
\hline Transcript & IDT PrimeTime qPCR assay & Accession no. & Location (bp) & Amplicon size (bp) \\
\hline Gnrhr & Mm.PT0.45.16240237 & NM_010323 & $542-634$ & 93 \\
Lhb & Mm.PT.45.5612498 & NM_008497 & $137-227$ & 91 \\
Egr1 & Mm.PT.45.13313108 & NM_007913 & $523-637$ & 115 \\
Fshb & Mm.PT.45.17694677 & NM_008045 & $1-105$ & 104 \\
Fst & Mm.PT.45.6344184 & NM_008046 & $1295-1382$ & 88 \\
Npffr1 & Mm.PT.49a.12363343 & NM_001177511 & $342-469$ & 128 \\
\hline
\end{tabular}

equivalent volume of saline intraperitoneally. Mice were decapitated 15 min postinjection, and trunk blood and pituitaries were collected. The GnRH dose $(150 \mathrm{ng} / \mathrm{kg})$ was chosen based on a dose-response curve (12.5-200 ng/kg GnRH) to result in a physiological LH response in both adults and day 21 pups. Serum LH and follicle-stimulating hormone (FSH) were measured in singlicate by the University of Virginia Center for Research and Reproduction Ligand Assay and Analysis Core using the Milliplex Rat Pituitary panel customized for LH/FSH (Millipore). The sensitivity of these two assays, as determined by the Ligand Assay and Analysis Core, is $0.24 \mathrm{ng} / \mathrm{ml}$ for $\mathrm{LH}$ and $2.4 \mathrm{ng} / \mathrm{ml}$ for FSH. The intraassay coefficient of variation was $10.3 \%$. All samples were run in the same assay to avoid interassay variability.

Pituitary RNA extraction and gene expression. Pituitaries were stored in RNA Later (Ambion, Life Technologies) at $-20^{\circ} \mathrm{C}$ until RNA extraction. RNA was extracted (with on-column DNasing) using RNeasy spin columns (Qiagen). Pituitary RNA ( $10 \mathrm{ng} / \mu$ l final concentration) and a standard curve of generic adult mouse pituitary RNA $(200,25,3.13,0.39,0.05$ $\mathrm{ng} / \mu \mathrm{l}$ final concentration) were reverse transcribed as described previously (Ruka et al., 2013). Because of limited RNA yield in neonatal pituitaries, pituitary cDNA (30 ng total) and the standard curve (1200, 150, $18.75,2.34,0.29 \mathrm{ng}$ ) were preamplified using TaqMan PreAmp Master Mix (Applied Biosystems). TaqMan primer-probes included for preamplification were for mRNAs of: Gnrhr, Lhb, Fshb, Egr1, follistatin (Fst), Npffrl, Lhb primary transcript (PT), Fshb PT, and housekeeping mRNAs Gapdh, Ppia, Actin, and Rps29. All Primer-probes were purchased from Integrative DNA Technologies (Tables 1,2). Primer-probes were resuspended in Tris-EDTA to $20 \times(5 \mu \mathrm{M}$ each primer, $10 \mu \mathrm{M}$ probe $)$ as recommended. The components for the preamplification reaction were as follows: $6 \mu \mathrm{l} \mathrm{cDNA}, 0.2 \times$ final concentration of each primer-probe, 12 $\mu \mathrm{l}$ of $2 \times$ preamplification buffer and water to a final volume of $24 \mu \mathrm{l}$. cDNA was preamplified for 15 cycles using the manufacturer recommended cycling conditions. The preamplified cDNAs were then diluted 1:20 with Tris-EDTA, a further dilution of 1:500, for use with the more abundant transcripts (LHb, Fshb, Rps29, Gapdh, Ppia, Actin) was also created. Preamplified cDNAs were stored at $-20^{\circ} \mathrm{C}$ until used for qPCR.

qPCR was performed using preamplified PCR product for each of the transcripts as described previously (Ruka et al., 2013). In short, $5 \mu \mathrm{l}$ of diluted preamplified PCR product were run in duplicate using TaqMan Gene Expression Master Mix (Applied Biosystems) for 40 cycles as indicated by the manufacturer. Linearity and parallelism of the preamplification step was confirmed as described previously (Ruka et al., 2013). Amplicon size was confirmed by agarose gel electrophoresis and sequencing for custom primer-probe sets. Relative gene expression was determined by the $\Delta-\Delta \mathrm{Ct}$ method (Livak and Schmittgen, 2001). Pituitary actin, Gapdh, and Ppia gene expression were regulated developmentally, thus relative gene expression was normalized to Rps29. To avoid intra-assay variability all samples were assayed within the same assay.

Differences in normalized relative gene expression were determined by two-way ANOVA with age and GnRH treatment as the main effects, with differences for either GnRH treatment or age were determined post hoc by Holm-Sidak test (Graphpad Prism 6).

Pituitary protein extraction and gene expression. Protein was extracted, quantified, and western blots of pituitary protein $(20 \mu \mathrm{g})$ from adult male mice injected with either saline or $150 \mathrm{ng} / \mathrm{kg}$ GnRH i.p., and then killed 5,15 , or 30 min postinjection ( $n=2-3$ per group) as reported by Burger et al. (2009). As a positive control for GnRH-induced ERK acti- vation (phosphorylation), gonadotrope-derived $\alpha \mathrm{T} 3$ cells were treated with either saline or $200 \mathrm{~nm} \mathrm{GnRH}$ for $10 \mathrm{~min}$. Blots were immunostained for dually phosphorylated (phospho) ERK1/2 (Cell Signaling Technology, Catalog \#4370), total ERK1/2 (Cell Signaling Technology, Catalog \#4695), and $\alpha$-tubulin (Thermo, Catalog \#RB-9281-P1).

\section{Results \\ Frequency of GnRH release detected by FSCV in the ME resembles that of $\mathrm{LH}$ release in vivo}

We recently adapted the electrochemical method of FSCV to detect GnRH secretion directly in mouse brain slices (Glanowska et al., 2012). FSCV directly detects the oxidation of secreted GnRH on carbon fiber microelectrodes. Because the analysis of FSCV requires background subtraction, basal levels cannot be assessed and we thus refer to "changes in GnRH concentration." We first determined the frequency of spontaneous GnRH secretion detected by FSCV on electrodes placed in the ME of brain slices acutely prepared from gonad-intact male mice (Figs. $1 B-D, 2 D-$ $G)$. The ME is the main site of GnRH release for control of the pituitary gland. In slices from adults, the frequency of spontaneous GnRH release detected by FSCV (as GnRH concentration changes) was $0.3 \pm 0.1$ events/h. This is similar to reports of $\mathrm{LH}$ pulse frequency in vivo in adult mice (Coquelin and Desjardins, 1982; Steyn et al., 2013), demonstrating a good match between FSCV measures in the ME of brain slices and functioning of the in vivo hypothalamic-pituitary-gonadal (HPG) axis. As an additional control, dopamine (5-50 $\mu \mathrm{M})$ was applied near electrodes placed in the cortex. No signal was produced with the waveform used for GnRH detection (Fig. 1E).

\section{Changes in spontaneous $\mathrm{GnRH}$ release during development}

Developmental changes in the pattern of spontaneous $\mathrm{GnRH}$ secretion were examined using FSCV starting at E18). Release frequency, peak amplitude and event duration were used to characterize GnRH secretion patterns. A very high-frequency release was observed in both embryonic (E18) and neonatal (P1) mice (Fig. 2A,D). At these developmental stages, the frequency of GnRH secretion was higher $(p<0.0001)$ than the highest frequency previously reported in adults in vivo in any species under any experimental condition (Webster et al., 1991). Surprisingly, this high-frequency GnRH release continued in mice monitored at 7-9 d of age, well beyond the very brief perinatal LH rise reported in this species (Poling and Kauffman, 2012). This GnRH release was calcium-dependent, suggesting it is vesicle-mediated and not leakage from damaged tissue (Fig. $2 B, C$ ). In marked contrast to the high release frequency up to $9 \mathrm{~d}$ of age, at 2 and 3 weeks the system was essentially shut down; a total of only two spontaneous release events were observed in slices from six mice at each age despite extending the recording duration to $4 \mathrm{~h}$. All of these preparations released GnRH in response to depolarization with $20 \mathrm{~mm} \mathrm{KCl}$ (Table 3). This paucity of spontaneous release was qualitatively different to that in adults, in which spontaneous GnRH release was observed in all slices within $4 \mathrm{~h}$. The statistical dilemma of demonstrating differences between numerically low values precluded differentiating release frequency in adults from that at 2 or 3 weeks of age.

With regard to release parameters other than frequency, a steady increase with age was observed in the magnitude of each GnRH release and a corresponding increase in duration of events (Figs. 2E, F, 3), which was shortest at E18 (80\% of release events lasting $<20 \mathrm{~s}$ ), and increased with age to reach durations $>1 \mathrm{~min}$ in adults (Figs. 2F, 3). Interestingly, age-related changes in spontaneous GnRH release frequency were inversely correlated with 
Table 2. Custom qPCR primers and probes for pituitary gene expression

\begin{tabular}{llcllll}
\hline Transcript & Accession no. & Location $(\mathrm{bp})$ & Amplicon size $(\mathrm{bp})$ & FWD primer & REV primer & Probe \\
\hline LhbPT & U25145 & $638-858$ & 221 & CAGTCTGCATCACCTTCACC & CGGCAGTACTCGGACCTG & GTCCTAGCATGGTGAGCGGG \\
FshbPT & NC_000068 & $107059078-107058934$ & 145 & CAAGCCGAAGACTTGAGAGG & GCAAAGCTGGATCAACTTCA & TCAGCTGTCAGTTTCACAGTGA \\
Rps29 & NM_009093 & $119-145$ & 127 & TGAAGGCAAGATGGGTCAC & GCACATGTTCAGCCCGTATT & AGTCACCCACGGAAGTTCGG \\
\hline
\end{tabular}
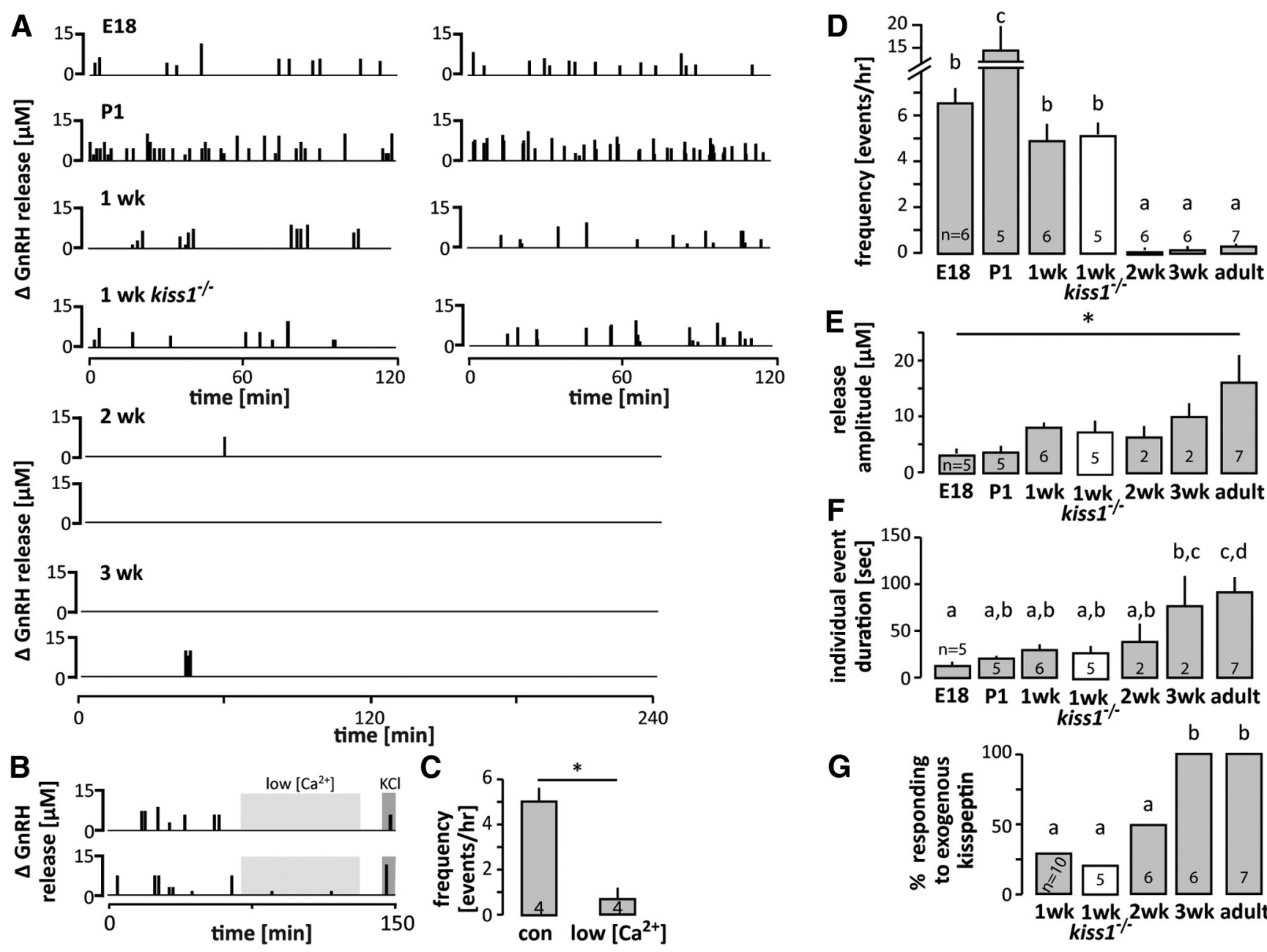

G

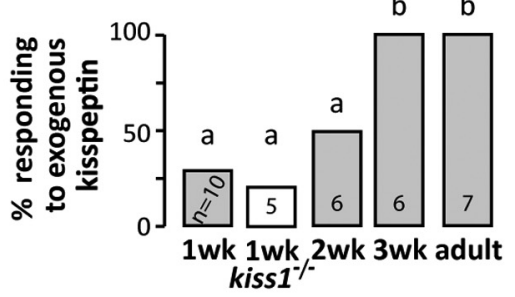

Figure 2. Developmental changes in spontaneous $G n R H$ release. $A$, Two representative examples of the pattern of spontaneous $G n R H$ release at each developmental age studied in wild-type mice and in kisspeptin $\mathrm{KO}$ mice (kiss 1 -/-) at 1 week. Each vertical bar represents an individual GnRH release event. $\boldsymbol{B}$, Two representative examples of spontaneous $\mathrm{GnRH}$ release in 1-wk-old mice in low calcium solution; light gray: low calcium ( $0.5 \mathrm{~mm}$ ) buffer present in the recording chamber; dark gray: high KCI ( $20 \mathrm{~mm}$ ) normal calcium ACSF in the recording chamber to evoke GnRH secretion. C, Mean \pm SEM frequency of GnRH release in normal (con) and low calcium ACSF; $p<0.05$, paired $t$ test. $D-G$, Mean \pm SEM characteristics of spontaneous GnRH release; numbers within/above bars represent sample size. $D$, Frequency of GnRH secretion expressed as number of release events per hour; different letters represent statistical significance; $p<0.0001$, one-way ANOVA followed by Tukey's multiple-comparison test. $\boldsymbol{E}$, Amplitude of $\mathrm{GnRH}$ release; ${ }^{*} p<0.05$, one-way ANOVA followed by Tukey's multiple-comparison test. $\boldsymbol{F}$, Duration of individual events; different letters represent statistical significance; $p<0.0001$, one-way ANOVA followed by Tukey's multiple-comparison test. $\mathbf{G}$, Responsiveness to 10 nm kisspeptin; different letters represent statistical significance; $p<0.01, \chi^{2}$ test.

responsiveness to kisspeptin, an important excitatory neuromodulator of GnRH release (Irwig et al., 2004; Plant et al., 2006; Pielecka-Fortuna et al., 2008). Kisspeptin injected locally in the ME evoked GnRH release in only 2 of 6 of slices from 1-week-old mice; in contrast, 3 -week-old and adult slices were $100 \%$ responsive (Fig. 2G).

Early prepubertal regulation of $\mathrm{GnRH}$ release

To examine why release frequency was so high in early prepubertal animals, we conducted a series of studies in 1-week-old mice; this age was chosen as an example of high-frequency release separated from the stress of recent parturition. Low responsiveness to kisspeptin in 1-week-old mice (Fig. 2G) combined with the high secretory activity of GnRH neurons at this age suggested two possibilities. First, GnRH release may be kisspeptin-independent at this age; second, response to exogenous kisspeptin may be occluded by high endogenous kisspeptin release. We thus recorded spontaneous GnRH secretion from 6 to 9-d-old male kisspeptin KO mice (Lapatto et al., 2007; Chan et al., 2009). There was no difference in the frequency of GnRH release, event amplitude, duration or responsiveness to kisspeptin between kisspeptin $\mathrm{KO}$ and wild-type animals (Fig. 2). High-frequency GnRH release in 1-week-old male mice is thus kisspeptin independent.

We next hypothesized that the elevated GnRH secretory activity is attributable to a lack of sufficient inhibition. First, we tested whether $\mathrm{GnIH}$, a negative neuromodulator of $\mathrm{GnRH}$ neurons 
Table 3. Spontaneous versus evoked $\mathrm{GnRH}$ secretion

\begin{tabular}{llll}
\hline Age group & $\begin{array}{l}\text { No. of } \\
\text { animals }\end{array}$ & $\begin{array}{l}\text { Animals with spontaneous } \\
\text { GnRH release }\end{array}$ & $\begin{array}{l}\text { Animals with KCl-evoked } \\
\text { GnRH release }\end{array}$ \\
\hline E18 & 6 & 6 & 6 \\
P1 & 5 & 5 & 5 \\
1 week & 6 & 6 & 6 \\
1 week kiss K0 & 5 & 5 & 5 \\
2 week & 6 & 2 & 6 \\
3 week & 6 & 2 & 6 \\
Adult & 7 & 7 & 7
\end{tabular}

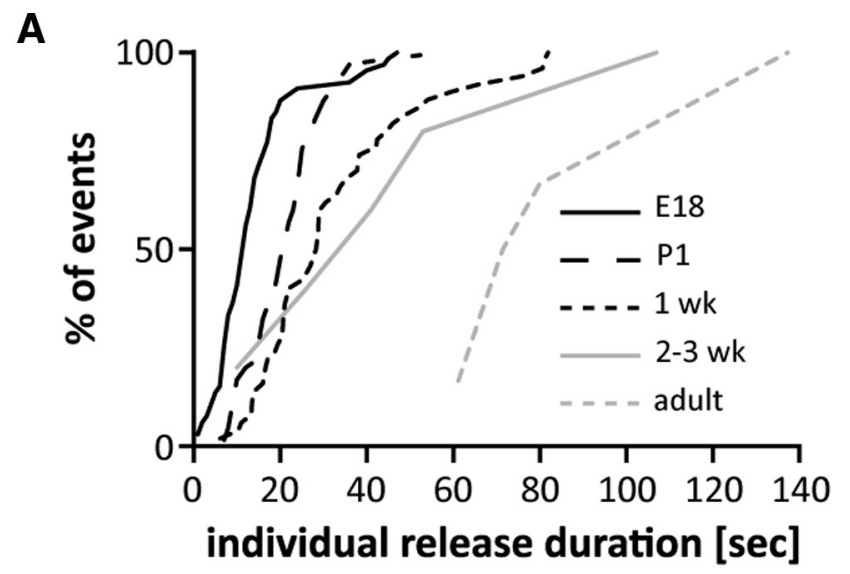

B

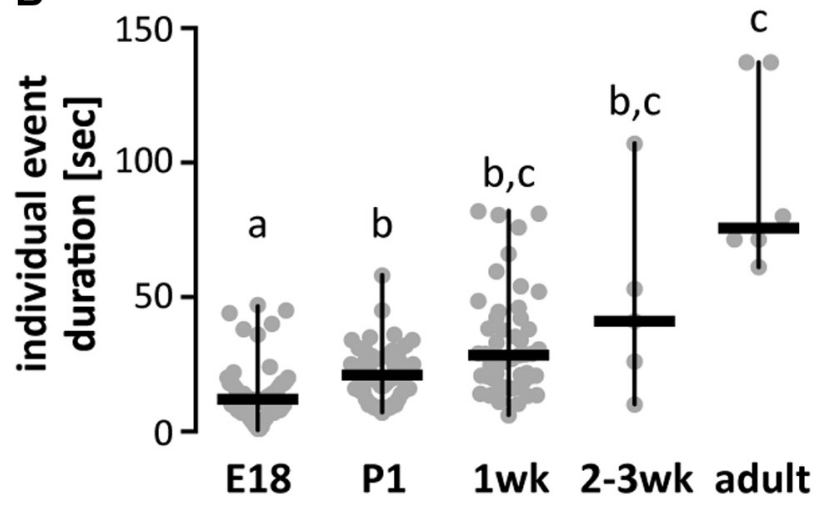

Figure 3. GnRH release events appear to consolidate with age, resulting in lower-frequency, longer duration release. $\boldsymbol{A}$, Cumulative distribution function of duration of all individual $\mathrm{GnRH}$ events in different age groups. Data for 2- and 3-week-old mice were combined attributable to paucity of events. $\boldsymbol{B}$, Duration for all individual GnRH events (gray circles), same groups as in $\boldsymbol{A}$; horizontal lines, data median; vertical lines, data range; different letters represent statistical significance; $p<0.0001$, Kruskal-Wallis test followed by Dunn's multiple-comparison test.

and the HPG axis (Ducret et al., 2009; Wu et al., 2009; Tsutsui et al., 2010), is capable of decreasing GnRH release frequency in 1-week-old mice (Fig. 4). GnIH (1 $\mu \mathrm{M})$ reduced $\mathrm{GnRH}$ release frequency and amplitude, suggesting a lack of endogenous inhibitory central input at this age (Fig. $4 B, C ; p<0.01$ ). The decrease in the frequency of $\mathrm{GnRH}$ secretion during $\mathrm{GnIH}$ treatment is in contrast to untreated slices from 1-week-old mice. There was no difference in release frequency between the first and second hour of recording in the absence of $\mathrm{GnIH}$ (Fig. 4B; further analysis of data from Fig. 2). We next asked whether testosterone inhibited $\mathrm{GnRH}$ release at 1 week. Mice received $50 \mathrm{mg} / \mathrm{kg}$ testosterone subcutaneously $4 \mathrm{~h}$ before brain slice preparation (Fig. $4 D$ ). In testosterone-treated mice, $\mathrm{GnRH}$ release frequency was reduced $(p<0.01)$, whereas release was unaffected in vehicle-injected
A

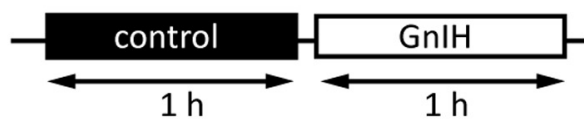

B
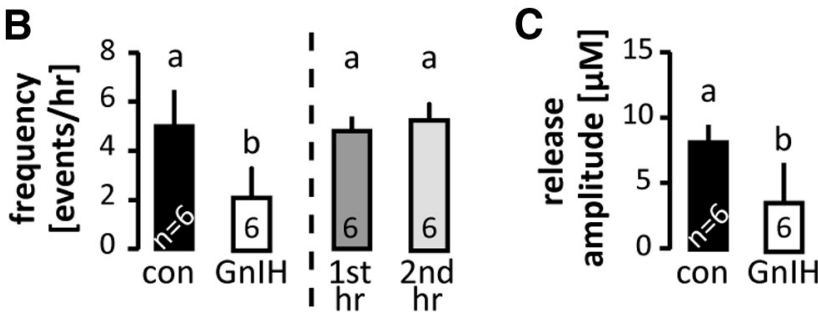

D

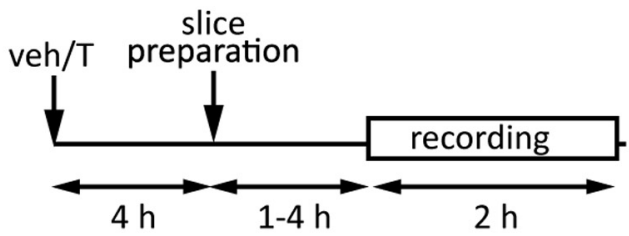

slice

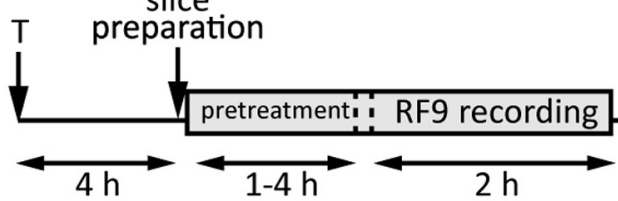

E
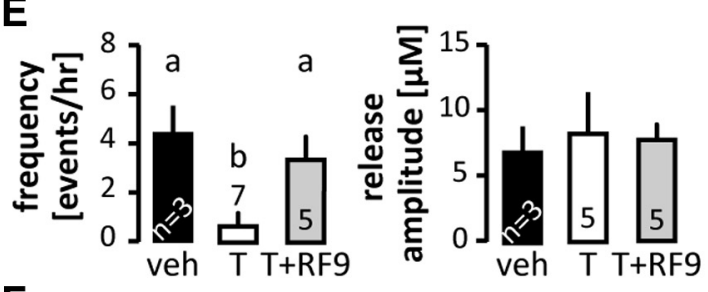

$F$
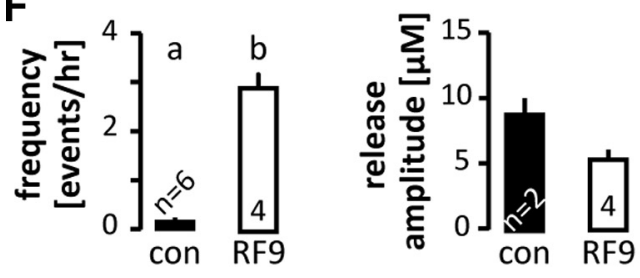

Figure 4. GnIH and testosterone inhibition of spontaneous GnRH secretion. $A$, Experimental design for the effect of $\mathrm{GnIH}$ on $\mathrm{GnRH}$ release in 1-week-old animals; $1 \mathrm{~h}$ of control recording (white block) followed by $1 \mathrm{~h}$ of recording in the presence of $1 \mu \mathrm{m} \mathrm{GnIH}$. B, Left, Frequency of spontaneous $\mathrm{GnRH}$ release under control conditions and incubation with $1 \mu \mathrm{m} \mathrm{GnIH}$. Right, Frequency of spontaneous $\mathrm{GnRH}$ release during the first versus second hours of recording under conditions (data from Fig. 2); $p<0.05$ paired $t$ test. C, Amplitude of spontaneous GnRH release under control conditions and incubation with $1 \mu \mathrm{m} \mathrm{GnIH}, p<0.05$ paired $t$ test. $D$, Experimental design for the effect of peripheral testosterone (T) administration on GnRH release (top); black arrows, timing of T/vehicle (veh) injection or slice preparation; white bar, timing of recording. Experimental design for the effect of $5 \mu \mathrm{MRF9}$ on T-induced decrease of GnRH release (bottom); black arrows, timing of T administration or slice preparation; gray bar, 1-4 h of slice pretreatment with RF9 followed by $2 \mathrm{~h}$ of recording in the presence of RF9. E, Effects of in vivo testosterone injection with and without in vitro RF9 incubation on frequency (left) and amplitude (right) of spontaneous $\mathrm{GnRH}$ secretion, $p<0.01$, one-way ANOVA followed by Tukey's multiple-comparison test. $\boldsymbol{F}$, Frequency and amplitude of spontaneous GnRH release in slices from 2-week-old males incubated in RF9, $p<0.05$, $t$ test. Values are mean $\pm \mathrm{SEM}$; numbers within/above bars represent sample size, different letters represent statistical significance.

controls (Fig. 4E). To examine a possible relationship between these two inhibitory cues in regulating $\mathrm{GnRH}$ secretion from the $\mathrm{ME}$, we preincubated brain slices from testosterone-injected mice with RF9 (5 $\mu \mathrm{M})$, which inhibits the putative $\mathrm{GnIH}$ receptor, 
GPR147/NPFFR1, as well as GPR74/NPFFR2 (Fig. 4D). This treatment restored GnRH frequency to levels observed in untreated mice (Fig. 4E). These observations strongly suggest testosterone action at 1 week of age is at least in part mediated by GPR147/GPR74 signaling.

The marked shut down in spontaneous release activity that occurs between 1 week of age, when GnIH was able to inhibit spontaneous GnRH release, and 2 weeks of age, when there was little spontaneous $\mathrm{GnRH}$ release suggests either net activation of inhibitory inputs to GnRH neurons or net suppression of excitatory inputs. Because endogenous kisspeptin was not required for the high-frequency release at 1 week of age and exogenous kisspeptin was effective only in a minority of experiments, and because preliminary data indicate fast synaptic inputs via either GABA or glutamate are very low-frequency through 2 weeks of age (R.A. DeFazio and S.M. Moenter, unpublished observation), we postulated that inhibitory inputs were activated. As exogenous GnIH successfully suppressed GnRH release at 1 week of age, we tested the hypothesis the activation of endogenous $\mathrm{GnIH}$ signaling might be responsible for the shut down in spontaneous GnRH release. To do this, we used RF9 to block GPR147/GPR74 signaling in 2-week-old mice, which show almost no spontaneous GnRH release, and examined GnRH release frequency. Brain slices were preincubated in RF9 and then spontaneous secretory activity in the ME monitored for $90 \mathrm{~min}$ in RF9. We observed a significant increase in the frequency, but not amplitude (Fig. $4 F$ ) or event duration (data not shown) compared with untreated controls. This indicates a possible role for $\mathrm{GnIH}$ or some other endogenous activator of these receptors in inhibiting the GnRH system at this age. There is an additional caveat beyond RF9 acting at both GPR147 and GPR74 that is important to consider. It is possible that RF9 has off-target actions as an agonist on a stimulatory receptor. Similarities in C-terminal structure of $\mathrm{GnIH}$ with kisspeptin might indicate the kisspeptin receptor as a possible target. Although the present data cannot rule this, or another, off-target action out, it is notable that the $\mathrm{GnRH}$ release in response to kisspeptin occurs only in a portion $(\sim 50 \%)$ of slices from mice 1 and 2 weeks of age, whereas RF9 had a consistent effect to increase $\mathrm{GnRH}$ release in $100 \%$ of preparations tested at 2 weeks of age. Further, when kisspeptin did evoke release, it was with a very short delay, typically $<1 \mathrm{~min}$, whereas RF9 required preincubation to be effective.

\section{Pituitary responsiveness to GnRH}

High-frequency GnRH secretion in 1-week-old males was unexpected based on low reported values of LH at that age (Wilson and Handa, 1997; Zapatero-Caballero et al., 2004; Gill et al., 2012). Continuous or very high-frequency GnRH infusion leads to desensitization of pituitary response and thus to decreased LH synthesis and release from the pituitary (Wildt et al., 1981; Lerrant et al., 1995). Although administration of high-frequency GnRH has been used to probe the relationship between frequency and pituitary response, the frequencies used in those studies (up to 5 pulses/h, rhesus monkey; Belchetz et al., 1978) had not previously been observed for spontaneous GnRH release (highest frequencies observed $\sim 3$ pulses $/ \mathrm{h}$, thyroidectomized sheep; Webster et al., 1991), and thus, whereas a useful tool, were considered outside the physiologic range. We hypothesized that endogenous production of these high frequencies in 1-week-old mice would induce a similar pituitary shutdown. We tested pituitary response to an exogenous GnRH pulse over development in male mice. Mice received either saline or $150 \mathrm{ng} / \mathrm{kg}$ GnRH intraperitoneally; serum and pituitaries were collected

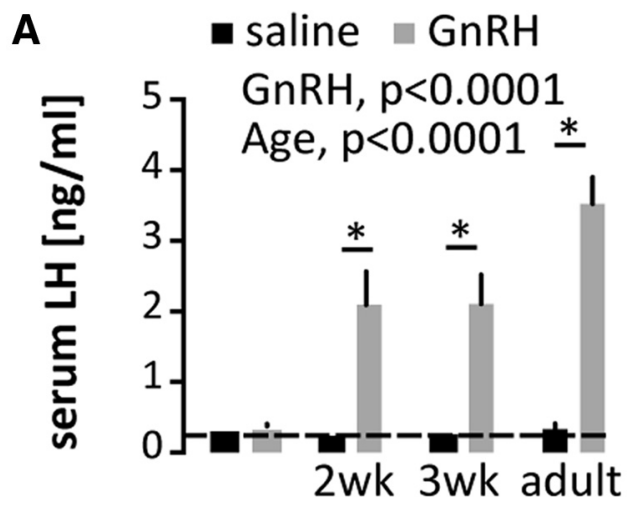

B

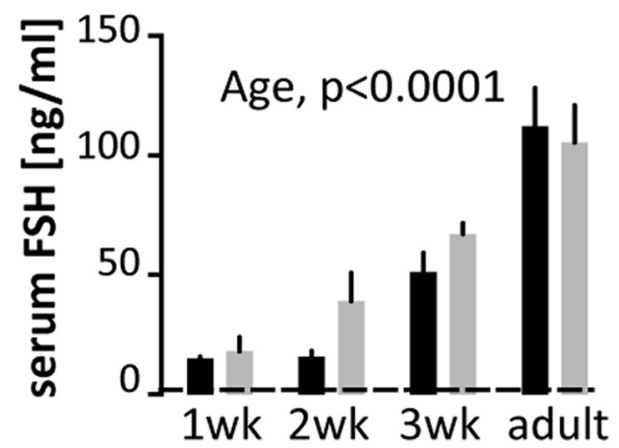

Figure 5. Failure of pituitary secretory response to exogenous $\mathrm{GnRH}$ at ages exhibiting high spontaneous $\mathrm{GnRH}$ release frequency. $\mathrm{GnRH}$-induced $\mathrm{LH}(\boldsymbol{A})$ and FSH $(\boldsymbol{B})$ release in males. Data are represented as mean \pm SEM, two-way ANOVA followed by Holms-Sidak multiple-comparison test (P1 animals were excluded from this analysis as no GnRH challenge was performed in this group); ${ }^{*} p<0.01$. Dashed lines indicate assay sensitivity. Note the different $\boldsymbol{y}$-axis scales in $\boldsymbol{A}$ and $\boldsymbol{B}$.

15 min later. Serum $\mathrm{LH}$, which reflects responsiveness to GnRH, was below detection levels in both saline- and GnRHinjected males at 1 week, as well as in noninjected newborns (Fig. 5A). In contrast, mice at all other ages exhibited an increase in LH following GnRH injection $(p<0.01)$. There was no clear response to GnRH in serum FSH levels (Fig. 5B), likely attributable to the more constitutive nature of its release (McNeilly et al., 2003).

To gain insight into possible mechanisms underlying the failure of GnRH to induce LH release, we examined pituitary expression of selected genes from male pituitaries (Fig. 6). GnRH receptor (GnRHR) mRNA is abundant in very young animals, although at lower levels than in adults, but importantly did not change between 1 and 2 weeks of age, despite the acquisition of response to exogenous GnRH. To assess the function of the GnRHR, we tested expression of genes targeted by GnRHR signaling pathway. Age-related increases $(p<0.0001)$ in expression of $\mathrm{LH} \beta$ and $\mathrm{FSH} \beta$ mRNA were observed, however, there were no differences in response to a single GnRH injection (Fig. $6 D, F$ ). Similarly, LH $\beta$ and FSH $\beta$ primary transcript expression increases with age $(p<0.0001)$, but a single GnRH injection induced $\mathrm{LH} \beta$ response only in adult mice $(p<0.05)$ and had no effect on $\mathrm{FSH} \beta$ at any age tested. Egrl, an immediate early gene induced by GnRHR signaling, shows similar pattern of expression changes with age $(p<0.0001)$, but no response to a single GnRH injection. Interestingly, expression of both Fst and GnIH receptor (Npffr1), which are upregulated by high-frequency GnRH pulses (Kirk et al., 1994; Dalkin et al., 1999; Burger et al., 2002; Sukhbaatar et al., 2014), was increased in early prepubertal 

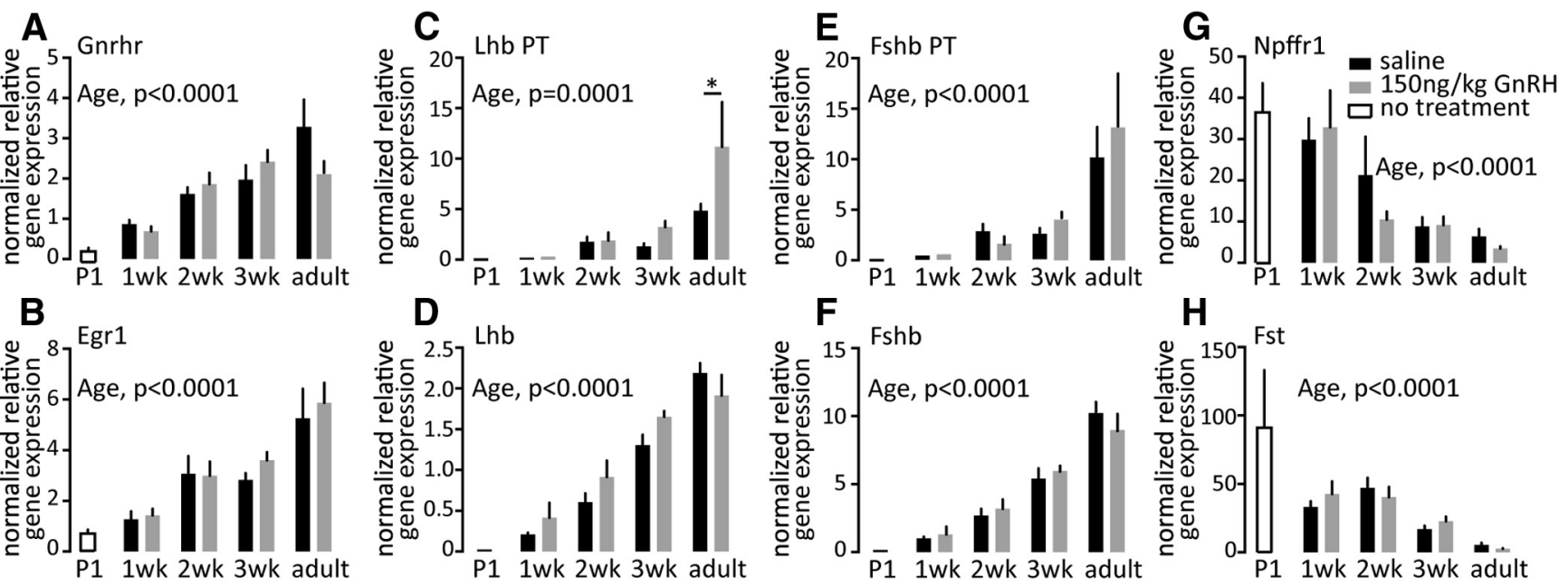

Figure 6. Effect of GnRH on expression of selected pituitary genes as a function of age. $\boldsymbol{A}-\boldsymbol{H}$, Normalized relative gene expressions for $\operatorname{Gnrhr}(\boldsymbol{A}), \operatorname{Egr} 1(\boldsymbol{B}), \operatorname{Lhb}$ PT (C), Lhb steady-state mRNA (D), Fshb PT (E), FSHb steady-state mRNA $(\boldsymbol{F})$, GnlH receptors/GPR147/GPR74 (Npffr1/Npffr2); $\boldsymbol{G}$ ), and Fst $(\boldsymbol{H})$. Pituitary gene expression was normalized to ribosomal protein S29 mRNA (Rps29), which did not change with either age or $\mathrm{GnRH}$ treatment. Data are represented as mean $\pm \mathrm{SEM}$, two-way ANOVA followed by Holms-Sidak multiple-comparison test (P1 animals were excluded from this analysis).

groups, and decreased with age $(p<$ $0.0001)$; elevation of these transcripts is an independent in vivo correlation of highfrequency GnRH release. Attempts to examine signaling pathway activation by GnRH were unsuccessful (Fig. 7), likely attributable to gonadotropes being a small percentage of the pituitary and signaling pathways being more ubiquitous among pituitary cell types than the mRNAs tested, which are enriched in the gonadotrope population. Of note, most studies of GnRH activation of pituitary phospho-ERK have been done in gonadectomized/steroidreplaced neuroendocrine suppression models to decrease basal pituitary ERK phosphorylation. The high basal pituitary phospho-ERK in the unsuppressed mice in the present study likely contributed to difficultly in observing ERK activation in response to GnRH.

\section{Discussion}

GnRH release before puberty in most species is assumed to be relatively low based on pituitary gonadotropin levels (Chowdhury and Steinberger, 1976). Here we used FSCV to directly measure $\mathrm{GnRH}$ release in brain slices from mice and demonstrate that this neuronal network secretes GnRH at very highfrequencies from at least the late embryonic period through the first week of postnatal life.

The present direct observations of GnRH release revealed surprisingly high-frequency release in the late embryonic and early postnatal period. High-frequency release persisted for at least a week after the immediate postnatal elevation in hormones (Poling and Kauffman, 2012). This frequent secretion may reflect intrinsic activity of the GnRH system without functional neuro-
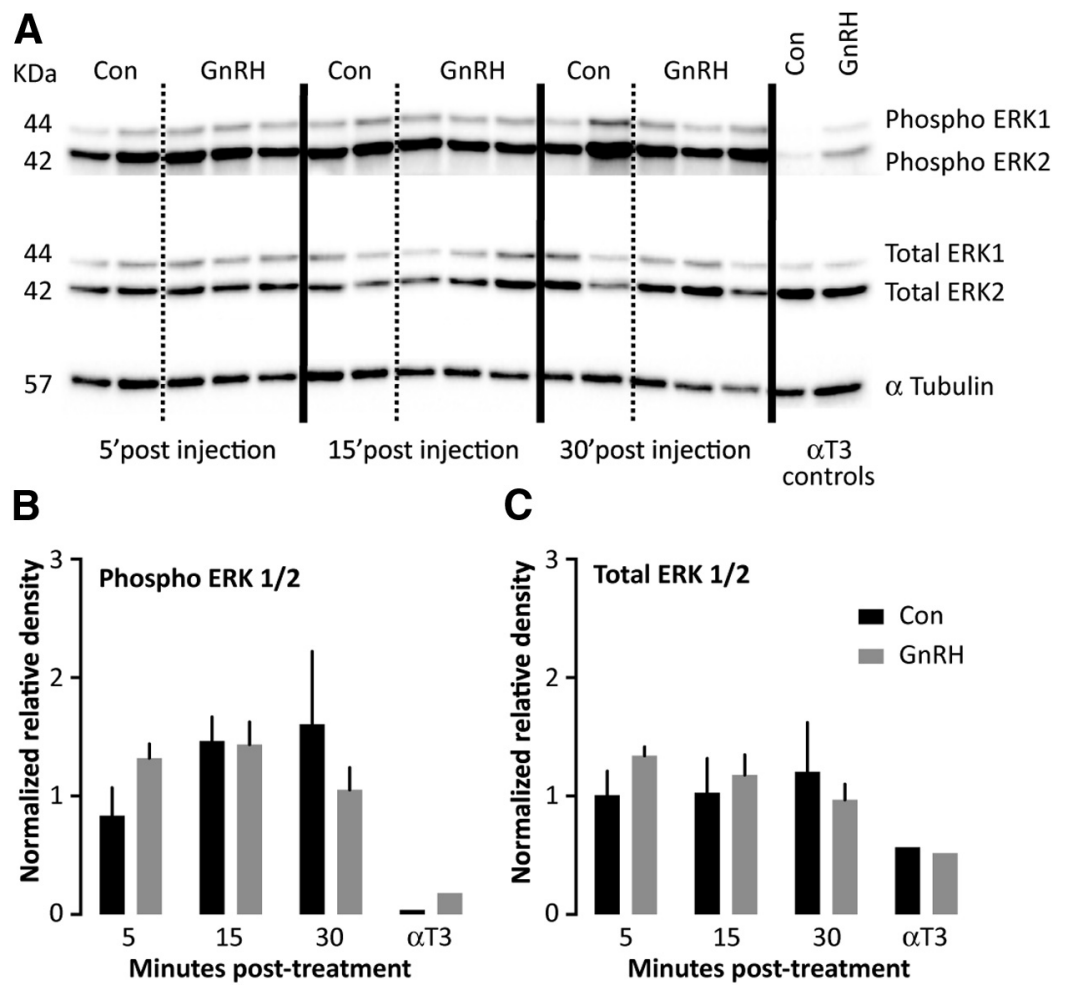

Figure 7. GnRH-induced intracellular signaling in mouse pituitaries, in vivo. $A$, Representative western blots of pituitary protein (20 $\mu \mathrm{g} /$ lane) from adult male mice injected with either saline or $150 \mathrm{ng} / \mathrm{kg} \mathrm{GnRH}$, intraperitoneally, and then killed 5, 15, or $30 \mathrm{~min}$ postinjection ( $n=2-3$ per group) or from $\alpha \mathrm{T}$ cells treated with either saline or $200 \mathrm{~nm} \mathrm{GnRH} \mathrm{for} 10 \mathrm{~min}$. Blots were immunostained for dually phosphorylated (phospho) ERK1/2, total ERK1/2, and $\alpha$-tubulin. B, C, Changes in phosphorylated ( $\boldsymbol{A}$ ) and total (B) ERK1/2 were quantified by densitometry.

modulatory input. Consistent with this hypothesis, early-life $\mathrm{GnRH}$ release is kisspeptin-independent, despite recent evidence that synaptic connections between GnRH and kisspeptin neurons are formed as early as E16.5 (Kumar et al., 2014). Further, endogenous $\mathrm{GnIH}$ signaling appears to be absent, demonstrated by the effective suppression of $\mathrm{GnRH}$ release by exogenous $\mathrm{GnIH}$. Of interest and somewhat counter to a currently prevailing view that $\mathrm{GnRH}$ release is kisspeptin-dependent, intrinsic activity is a hall- 
mark of cultured embryonic and immortalized GnRH neurons, which exhibit patterned action potentials, hormone release, and calcium oscillations (Krsmanović et al., 1992; Terasawa et al., 1999; Nunemaker et al., 2001).

Although the GnRH neuronal network present in the brain slices used in these studies can generate high-frequency release, release at this frequency may not be interpretable by the pituitary as a stimulatory signal as suggested by the lack of LH secretory response to GnRH in 1-week-old mice. It is possible the lack of response to a single injection is attributable to a lack of priming, but pituitaries of 2-week-old mice respond despite no priming and little endogenous GnRH. GnRH release in early prepubertal animals is short duration and low amplitude and thus may not reach the pituitary. Follistatin mRNA levels are elevated in 1-week-old mice, however, and are upregulated by highfrequency GnRH. Of note, GnRH release pattern from E18 to 1 week was irregular, in contrast to the typically uniform pattern of release observed in adults in vivo (Karsch et al., 1987; Moenter et al., 1992; Sisk et al., 2001). This may be an artifact of having removed important regulatory regions during the preparation of brain slices, but may also reflect the immaturity of the afferent network remaining within the slice. Continuous or high-frequency GnRH administration suppresses pituitary gonadotropin release (Belchetz et al., 1978; Wildt et al., 1981). The observation that the high endogenous GnRH release frequency at 1week was associated with pituitary failure to respond to exogenous GnRH with gonadotropin release, suggests the pituitary's requirement for an appropriately patterned GnRH release has a potential role beyond promoting differential gonadotropin release in adults. Specifically, lack of pituitary gonadotropin release when confronted with high-frequency GnRH during early postnatal life effectively blocks activation of the downstream reproductive system, preventing precocious puberty.

Between 1 and 2 weeks postnatal, a marked change in GnRH release was observed. This coincides with increased GnRH response to kisspeptin and with the onset of pituitary LH release in response to exogenous GnRH. It is possible that during this interval endogenous $\mathrm{GnIH}$ signaling has matured and contributes to the marked suppression of endogenous GnRH release, restoring pituitary sensitivity. At 2 weeks, RF9, which appears to block a putative GnIH-receptor (NPFFR1) among other possible actions, increased GnRH release frequency. NPFFR1 receptor KO mice also exhibit reduced LH response to GnRH (León et al., 2014). The high-frequency, short duration, irregular GnRH release observed through 1 week of age, became longer and less frequent, organizing more into the pattern observed in vivo in adults, arguing for a more mature network remaining in the slice. Upstream neuromodulators including kisspeptin and GnIH may thus play their more important roles in organizing GnRH network activity in the later stages of the pubertal process, rather than generating GnRH activity per se. In addition to the increasing GnRH response to kisspeptin observed here and by others (Han et al., 2005), recent studies have pointed to epigenetic changes in the preoptic area and hypothalamus occurring at a similar age (Lomniczi et al., 2013). Further, ablation of kisspeptin neurons before P20 allows compensation of the overall network so that mice are fertile, whereas adult ablation consistently leads to infertility (Mayer and Boehm, 2011) suggesting a critical role for kisspeptin or other transmitters from these neurons (Cravo et al., 2011) becoming mandatory during the later prepubertal stages.
As with any experimental preparation, it is important to consider the caveats of the approach. FSCV can be fined tuned to detect specific substances; the protocol used in the present study detects no signal in the ME of hypogonadal mice even when neurosecretion is evoked by elevated extracellular potassium, demonstrating it is specific for GnRH (Glanowska et al., 2012). The signal FSCV detects is attributable to oxidation of GnRH and is thus a direct measure of hormone release. The size of the carbon fiber microelectrode is such that release is likely detected from several terminals. It is important to point out, however, that release events distal to the electrode cannot be detected. This would result in undercounting of release frequency. Because these measurements were made in a brain slice, the pattern of release is from a network that is missing elements that are removed by preparation of sagittal sections. Several observations suggest these measurements are still physiologically relevant. First, the frequency of release detected in slices from adults is similar to published reports of LH pulse frequency (Coquelin and Desjardins, 1982). Second, release is vesicle-mediated, not just leak from damaged tissue. Third, frequency does not change in a linear manner with age, which one might suspect if an artifact were merely changing over time. Fourth, regulation by testosterone and GnIH suggests at least some relevant afferent systems are preserved. Finally, the lack of $\mathrm{LH}$ response to GnRH at 1 week of age and restoration of that response at 2 weeks of age are what would be predicted if the frequencies observed in vitro were occurring in vivo.

Another limitation to this study is the difficulty in extrapolating these observations between species and even to female mice. Studies of very young laboratory animals, particularly in the first week to $10 \mathrm{~d}$ postnatal, are limited. Although there seems to be general agreement that gonadotropin levels are low, there are not any studies of $\mathrm{GnRH}$ release during this time for comparison. At slightly older ages, our observations tend to agree with the agerelated increase in frequency that has been observed in vitro (Bourguignon and Franchimont, 1984) and in vivo (Sisk et al., 2001). Comparisons with primates may be of limited value given the relatively unique developmental pattern presented by the prolonged postnatal activation of the hypothalamo-pituitary axis in these species (Plant and Witchel, 2006). Of interest, the present studies suggest a possible greater similarity between mice and primates at least at the level of GnRH release than was appreciated solely from measures of LH; that is in mice as well as primates, the GnRH system is activated, shut down, and then reactivated for completion of the final pubertal transition. Finally, it is important to point out that the developmental stages we examined cannot be broadly compared by age to most other species given the different levels of development at birth. Our sampling window was defined by practical matters; it began at E18 because the GnRH terminals have reached the ME in appreciable numbers and because it was possible to make quality brain slices at this age. For some species, the equivalent ages may occur much earlier in gestation.

The possible roles of abundant GnRH secretion long before it can exert downstream reproductive function are of interest to consider. The GnRH pulse generator, which is responsible for driving reproduction in adults, consists not only of GnRH neurons, but incorporates other neuronal and glial elements and integrates a variety of physiological cues, from energy balance to steroid milieu to circadian information. Such complexity requires proper connectivity among individual elements of the network. Activity-dependent genesis and elimination of synaptic connections is one of the major processes taking place in the 
developing brain (Toth et al., 2013). We speculate that the primary role of $\mathrm{GnRH}$ secretion from late embryonic through early postnatal development is neuromodulatory and that it is critical for establishment of proper wiring of the reproductive brain. In this regard, recent studies indicate GnRH can be secreted in regions other than the ME (Glanowska et al., 2012). Both functional (Davidson et al., 2004; Xu et al., 2004; Wen et al., 2010) and anatomical studies (Wen et al., 2011) indicate the presence of GnRHR in the brain. During their migration from the olfactory placode to the diencephalon, prenatally and in adults, GnRH has been proposed to exert neuromodulatory effects on both $\mathrm{GnRH}$ and other types of neurons (Davidson et al., 2004; Xu et al., 2004; Wen et al., 2010). In this regard, a role of GnRH or GnRH neuronal activity in organizing local circuitry during postnatal sexual development is postulated.

\section{References}

Belchetz PE, Plant TM, Nakai Y, Keogh EJ, Knobil E (1978) Hypophysial responses to continuous and intermittent delivery of hypothalamic gonadotropin-releasing hormone. Science 202:631-633. CrossRef Medline

Bourguignon JP, Franchimont P (1984) Puberty-related increase in episodic LHRH release from rat hypothalamus in vitro. Endocrinology 114: 1941-1943. CrossRef Medline

Burger LL, Dalkin AC, Aylor KW, Haisenleder DJ, Marshall JC (2002) GnRH pulse frequency modulation of gonadotropin subunit gene transcription in normal gonadotropes-assessment by primary transcript assay provides evidence for roles of $\mathrm{GnRH}$ and follistatin. Endocrinology 143: 3243-3249. CrossRef Medline

Burger LL, Haisenleder DJ, Aylor KW, Marshall JC (2009) Regulation of Lhb and Egrl gene expression by GNRH pulses in rat pituitaries is both c-Jun N-terminal kinase (JNK)- and extracellular signal-regulated kinase (ERK)-dependent. Biol Reprod 81:1206-1215. CrossRef Medline

Caraty A, Blomenröhr M, Vogel GM, Lomet D, Briant C, Beltramo M (2012) RF9 powerfully stimulates gonadotrophin secretion in the ewe: evidence for a seasonal threshold of sensitivity. J Neuroendocrinol 24:725-736. CrossRef Medline

Chan YM, Broder-Fingert S, Wong KM, Seminara SB (2009) Kisspeptin/ Gpr54-independent gonadotrophin-releasing hormone activity in Kiss1 and Gpr54 mutant mice. J Neuroendocrinol 21:1015-1023. CrossRef Medline

Chowdhury M, Steinberger E (1976) Pituitary and plasma levels of gonadotrophins in foetal and newborn male and female rats. J Endocrinol 69: 381-384. CrossRef Medline

Chu Z, Moenter SM (2005) Endogenous activation of metabotropic glutamate receptors modulates GABAergic transmission to gonadotropinreleasing hormone neurons and alters their firing rate: a possible local feedback circuit. J Neurosci 25:5740-5749. CrossRef Medline

Coquelin A, Desjardins C (1982) Luteinizing hormone and testosterone secretion in young and old male mice. Am J Physiol 243:E257-E263. Medline

Cravo RM, Margatho LO, Osborne-Lawrence S, Donato J Jr, Atkin S, Bookout AL, Rovinsky S, Frazão R, Lee CE, Gautron L, Zigman JM, Elias CF (2011) Characterization of Kiss1 neurons using transgenic mouse models. Neuroscience 173:37-56. CrossRef Medline

Dalkin AC, Haisenleder DJ, Gilrain JT, Aylor K, Yasin M, Marshall JC (1999) Gonadotropin-releasing hormone regulation of gonadotropin subunit gene expression in female rats: actions on follicle-stimulating hormone $\beta$ messenger ribonucleic acid (mRNA) involve differential expression of pituitary activin $(\beta-B)$ and follistatin mRNAs. Endocrinology 140:903908. CrossRef Medline

Davidson L, Pawson AJ, Millar RP, Maudsley S (2004) Cytoskeletal reorganization dependence of signaling by the gonadotropin-releasing hormone receptor. J Biol Chem 279:1980-1993. CrossRef Medline

Döhler KD, Wuttke W (1974) Serum LH, FSH, prolactin and progesterone from birth to puberty in female and male rats. Endocrinology 94:10031008. CrossRef Medline

Ducret E, Anderson GM, Herbison AE (2009) RFamide-related peptide-3, a mammalian gonadotropin-inhibitory hormone ortholog, regulates gonadotropin-releasing hormone neuron firing in the mouse. Endocrinology 150:2799-2804. CrossRef Medline

Foster DL, Jackson LM (2006) Puberty in the sheep. In: Physiology of reproduction, Ed 3 (Knobil E, Neill JD, eds), pp 2127-2176. St Louis: Academic.

Gaskins GT, Glanowska KM, Moenter SM (2013) Activation of neurokinin 3 receptors stimulates $\mathrm{GnRH}$ release in a location-dependent but kisspeptin-independent manner in adult mice. Endocrinology 154:39843989. CrossRef Medline

Gill JC, Navarro VM, Kwong C, Noel SD, Martin C, Xu S, Clifton DK, Carroll RS, Steiner RA, Kaiser UB (2012) Increased neurokinin B (Tac2) expression in the mouse arcuate nucleus is an early marker of pubertal onset with differential sensitivity to sex steroid-negative feedback than Kiss1. Endocrinology 153:4883-4893. CrossRef Medline

Glanowska KM, Venton BJ, Moenter SM (2012) Fast scan cyclic voltammetry as a novel method for detection of real-time gonadotropin-releasing hormone release in mouse brain slices. J Neurosci 32:14664-14669. CrossRef Medline

Goldman BD, Grazia YR, Kamberi IA, Porter JC (1971) Serum gonadotropin concentrations in intact and castrated neonatal rats. Endocrinology 88:771-776. CrossRef Medline

Han SK, Gottsch ML, Lee KJ, Popa SM, Smith JT, Jakawich SK, Clifton DK, Steiner RA, Herbison AE (2005) Activation of gonadotropin-releasing hormone neurons by kisspeptin as a neuroendocrine switch for the onset of puberty. J Neurosci 25:11349-11356. CrossRef Medline

Irwig MS, Fraley GS, Smith JT, Acohido BV, Popa SM, Cunningham MJ, Gottsch ML, Clifton DK, Steiner RA (2004) Kisspeptin activation of gonadotropin releasing hormone neurons and regulation of kiss- 1 mRNA in the male rat. Neuroendocrinology 80:264-272. CrossRef Medline

Karsch FJ, Cummins JT, Thomas GB, Clarke IJ (1987) Steroid feedback inhibition of pulsatile secretion of gonadotropin-releasing hormone in the ewe. Biol Reprod 36:1207-1218. CrossRef Medline

Kirk SE, Dalkin AC, Yasin M, Haisenleder DJ, Marshall JC (1994) Gonadotropin-releasing hormone pulse frequency regulates expression of pituitary follistatin messenger ribonucleic acid: a mechanism for differential gonadotrope function. Endocrinology 135:876-880. CrossRef Medline

Krewson TD, Supelak PJ, Hill AE, Singer JB, Lander ES, Nadeau JH, Palmert MR (2004) Chromosomes 6 and 13 harbor genes that regulate pubertal timing in mouse chromosome substitution strains. Endocrinology 145: 4447-4451. CrossRef Medline

Krsmanović LZ, Stojilković SS, Merelli F, Dufour SM, Virmani MA, Catt KJ (1992) Calcium signaling and episodic secretion of gonadotropinreleasing hormone in hypothalamic neurons. Proc Natl Acad Sci U S A 89:8462-8466. CrossRef Medline

Kumar D, Freese M, Drexler D, Hermans-Borgmeyer I, Marquardt A, Boehm U (2014) Murine arcuate nucleus kisspeptin neurons communicate with GnRH neurons in utero. J Neurosci 34:3756-3766. CrossRef Medline

Lapatto R, Pallais JC, Zhang D, Chan YM, Mahan A, Cerrato F, Le WW, Hoffman GE, Seminara SB (2007) Kiss $1^{-1-}$ mice exhibit more variable hypogonadism than Gpr54 ${ }^{-1-}$ mice. Endocrinology 148:4927-4936. CrossRef Medline

León S, García-Galiano D, Ruiz-Pino F, Barroso A, Manfredi-Lozano M, RomeroRuiz A, Roa J, Vázquez MJ, Gaytan F, Blomenrohr M, van Duin M, Pinilla L, Tena-Sempere M (2014) Physiological roles of gonadotropin-inhibitory hormone signaling in the control of mammalian reproductive axis: studies in the NPFF1 receptor null mouse. Endocrinology 155:2953-2965. CrossRef Medline

Lerrant Y, Kottler ML, Bergametti F, Moumni M, Blumberg-Tick J, Counis R (1995) Expression of gonadotropin-releasing hormone (GnRH) receptor gene is altered by $\mathrm{GnRH}$ agonist desensitization in a manner similar to that of gonadotropin beta-subunit genes in normal and castrated rat pituitary. Endocrinology 136:2803-2808. CrossRef Medline

Livak KJ, Schmittgen TD (2001) Analysis of relative gene expression data using real-time quantitative PCR and the $2\left(-\delta \delta C_{\mathrm{T}}\right)$ method. Methods 25:402-408. CrossRef Medline

Lomniczi A, Loche A, Castellano JM, Ronnekleiv OK, Bosch M, Kaidar G, Knoll JG, Wright H, Pfeifer GP, Ojeda SR (2013) Epigenetic control of female puberty. Nat Neurosci 16:281-289. CrossRef Medline

MacKinnon PC, Mattock JM, ter Haar MB (1976) Serum gonadotrophin levels during development in male, female and androgenized female rats and the effect of general disturbance on high luteinizing hormone levels. J Endocrinol 70:361-371. CrossRef Medline 
Mayer C, Boehm U (2011) Female reproductive maturation in the absence of kisspeptin/GPR54 signaling. Nat Neurosci 14:704-710. CrossRef Medline

McNeilly AS, Crawford JL, Taragnat C, Nicol L, McNeilly JR (2003) The differential secretion of FSH and LH: regulation through genes, feedback and packaging. Reprod Suppl 61:463-476. Medline

Michael SD, Kaplan SB, Macmillan BT (1980) Peripheral plasma concentrations of $\mathrm{LH}, \mathrm{FSH}$, prolactin and GH from birth to puberty in male and female mice. J Reprod Fertil 59:217-222. CrossRef Medline

Moenter SM, Brand RM, Midgley AR, Karsch FJ (1992) Dynamics of gonadotropin-releasing hormone release during a pulse. Endocrinology 130:503-510. CrossRef Medline

Mundroff ML, Wightman RM (2002) Amperometry and cyclic voltammetry with carbon fiber microelectrodes at single cells. Curr Protoc Neurosci 6:6.14. CrossRef

Nunemaker CS, DeFazio RA, Geusz ME, Herzog ED, Pitts GR, Moenter SM (2001) Long-term recordings of networks of immortalized GnRH neurons reveal episodic patterns of electrical activity. J Neurophysiol 86:86-93. Medline

Nunemaker CS, DeFazio RA, Moenter SM (2002) Estradiol-sensitive afferents modulate long-term episodic firing patterns of GnRH neurons. Endocrinology 143:2284-2292. CrossRef Medline

Ojeda SR, Skinner MK (2006) Puberty in the rat. In: Physiology of reproduction, Ed 3 (Knobil E, Neill JD, eds), pp 2061-2126. St Louis: Academic.

Ojeda SR, Lomniczi A, Sandau U (2010) Contribution of glial-neuronal interactions to the neuroendocrine control of female puberty. Eur J Neurosci 32:2003-2010. CrossRef Medline

O'Shaughnessy PJ, Baker P, Sohnius A, Haavisto AM, Charlton HM, Huhtaniemi I (1998) Fetal development of Leydig cell activity in the mouse is independent of pituitary gonadotroph function. Endocrinology 139: 1141-1146. CrossRef Medline

Pielecka-Fortuna J, Chu Z, Moenter SM (2008) Kisspeptin acts directly and indirectly to increase gonadotropin-releasing hormone neuron activity and its effects are modulated by estradiol. Endocrinology 149:1979-1986. CrossRef Medline

Plant TM, Witchel SF (2006) Puberty in nonhuman primates and humans. In: Physiology of reproduction, Ed 3(Knobil E, Neill JD, ed), pp 21772230. St Louis: Academic.

Plant TM, Ramaswamy S, DiPietro MJ (2006) Repetitive activation of hypothalamic G-protein-coupled receptor 54 with intravenous pulses of kisspeptin in the juvenile monkey (Macaca mulatta) elicits a sustained train of gonadotropin-releasing hormone discharges. Endocrinology 147: 1007-1013. CrossRef Medline

Poling MC, Kauffman AS (2012) Sexually dimorphic testosterone secretion in prenatal and neonatal mice is independent of kisspeptin-Kisslr and GnRH signaling. Endocrinology 153:782-793. CrossRef Medline

Poling MC, Kim J, Dhamija S, Kauffman AS (2012) Development, sex steroid regulation, and phenotypic characterization of RFamide-related peptide (Rfrp) gene expression and RFamide receptors in the mouse hypothalamus. Endocrinology 153:1827-1840. CrossRef Medline

Ruka KA, Burger LL, Moenter SM (2013) Regulation of arcuate neurons coexpressing kisspeptin, neurokinin $\mathrm{B}$, and dynorphin by modulators of neurokinin 3 and $\kappa$-opioid receptors in adult male mice. Endocrinology 154:2761-2771. CrossRef Medline

Selmanoff MK, Goldman BD, Ginsburg BE (1977) Developmental changes in serum luteinizing hormone, follicle stimulating hormone and androgen levels in males of two inbred mouse strains. Endocrinology 100:122127. CrossRef Medline

Seminara SB, Crowley WF Jr (2001) Perspective: the importance of genetic defects in humans in elucidating the complexities of the hypothalamicpituitary-gonadal axis. Endocrinology 142:2173-2177. CrossRef Medline
Sisk CL, Richardson HN, Chappell PE, Levine JE (2001) In vivo gonadotropin-releasing hormone secretion in female rats during peripubertal development and on proestrus. Endocrinology 142:2929-2936. CrossRef Medline

Steyn FJ, Wan Y, Clarkson J, Veldhuis JD, Herbison AE, Chen C (2013) Development of a methodology for and assessment of pulsatile luteinizing hormone secretion in juvenile and adult male mice. Endocrinology 154: 4939-4945. CrossRef Medline

Sukhbaatar U, Kanasaki H, Mijiddorj T, Oride A, Miyazaki K (2014) Expression of gonadotropin-inhibitory hormone receptors in mouse pituitary gonadotroph $\mathrm{L} \beta \mathrm{T} 2$ cells and hypothalamic gonadotropin-releasing hormone-producing GT1-7 cells. Endocr J 61:25-34. CrossRef Medline

Suter KJ, Song WJ, Sampson TL, Wuarin JP, Saunders JT, Dudek FE, Moenter SM (2000) Genetic targeting of green fluorescent protein to gonadotropin-releasing hormone neurons: characterization of whole-cell electrophysiological properties and morphology. Endocrinology 141:412-419. CrossRef Medline

Terasawa E, Schanhofer WK, Keen KL, Luchansky L (1999) Intracellular $\mathrm{Ca}^{2+}$ oscillations in luteinizing hormone-releasing hormone neurons derived from the embryonic olfactory placode of the rhesus monkey. J Neurosci 19:5898-5909. Medline

Toth AB, Terauchi A, Zhang LY, Johnson-Venkatesh EM, Larsen DJ, Sutton MA, Umemori H (2013) Synapse maturation by activity-dependent ectodomain shedding of $\operatorname{SIRP} \alpha$. Nat Neurosci 16:1417-1425. CrossRef Medline

Tsutsui K, Bentley GE, Bedecarrats G, Osugi T, Ubuka T, Kriegsfeld LJ (2010) Gonadotropin-inhibitory hormone $(\mathrm{GnIH})$ and its control of central and peripheral reproductive function. Front Neuroendocrinol 31: 284-295. CrossRef Medline

Watanabe G, Terasawa E (1989) In vivo release of luteinizing hormone releasing hormone increases with puberty in the female rhesus monkey. Endocrinology 125:92-99. CrossRef Medline

Webster JR, Moenter SM, Barrell GK, Lehman MN, Karsch FJ (1991) Role of the thyroid gland in seasonal reproduction: III. Thyroidectomy blocks seasonal suppression of gonadotropin-releasing hormone secretion in sheep. Endocrinology 129:1635-1643. CrossRef Medline

Wen S, Ai W, Alim Z, Boehm U (2010) Embryonic gonadotropin-releasing hormone signaling is necessary for maturation of the male reproductive axis. Proc Natl Acad Sci U S A 107:16372-16377. CrossRef Medline

Wen S, Götze IN, Mai O, Schauer C, Leinders-Zufall T, Boehm U (2011) Genetic identification of GnRH receptor neurons: a new model for studying neural circuits underlying reproductive physiology in the mouse brain. Endocrinology 152:1515-1526. CrossRef Medline

Wildt L, Häusler A, Marshall G, Hutchison JS, Plant TM, Belchetz PE, Knobil E (1981) Frequency and amplitude of gonadotropin-releasing hormone stimulation and gonadotropin secretion in the rhesus monkey. Endocrinology 109:376-385. CrossRef Medline

Wilson ME, Handa RJ (1997) Ontogeny of gene expression in the gonadotroph of the developing female rat. Biol Reprod 56:563-568. CrossRef Medline

Wu M, Dumalska I, Morozova E, van den Pol AN, Alreja M (2009) Gonadotropin inhibitory hormone inhibits basal forebrain vGluT2gonadotropin-releasing hormone neurons via a direct postsynaptic mechanism. J Physiol 587:1401-1411. CrossRef Medline

Xu C, Xu XZ, Nunemaker CS, Moenter SM (2004) Dose-dependent switch in response of gonadotropin-releasing hormone $(\mathrm{GnRH})$ neurons to GnRH mediated through the type I GnRH receptor. Endocrinology 145: 728-735. CrossRef Medline

Zapatero-Caballero H, Sanchez-Franco F, Fernandez-Mendez C, García-San Frutos M, Botella-Cubells LM, Fernandez-Vazquez G (2004) Gonadotropin-releasing hormone receptor gene expression during pubertal development of female rats. Biol Reprod 70:348-355. CrossRef Medline 